\title{
Female Fertility and Single Nucleotide Polymorphism Comparisons in Cylindrocladium pauciramosum
}

\author{
Conrad L. Schoch and Pedro W. Crous, Department of Plant Pathology, University of Stellenbosch, Matieland \\ 7602, South Africa; Giancarlo Polizzi, Dipartimento di Scienze e Tecnologie Fitosanitarie, University of Catania, \\ Catania, Italy; and Steven T. Koike, University of California Cooperative Extension 1432, Salinas 93901
}

\begin{abstract}
Schoch, C. L., Crous, P. W., Polizzi, G., and Koike, S. T. 2001. Female fertility and single nucleotide polymorphism comparisons in Cylindrocladium pauciramosum. Plant Dis. 85:941-946.

Cylindrocladium pauciramosum is well established in South America, and has recently been collected from nurseries in South Africa, Italy, and the United States. Isolates were compared with respect to the percentages of hermaphrodites and the respective mating types in the different samples. Based on these data, the effective population size could be determined for the different areas studied. All nurseries had mating type ratios significantly different from an idealized 1:1 ratio. In the South African nursery, the MAT-1 mating type was dominant, while the MAT-2 mating type dominated in other samplings. This is consistent with an introduction of a small starter population. High percentages of hermaphrodites also agreed with recent introductions into nurseries in Italy and the United States. Variability of DNA sequences of the $5^{\prime}$ end of the $\beta$-tubulin gene from a set of $C$. pauciramosum isolates from different geographic regions was low to high. Isolates from South Africa, the United States, and Australia had identical $\beta$ tubulin DNA sequences; this sequence was also found in the Italian sample, along with another unique group. Finally, a group of isolates obtained from South and Central America had the highest variation of all isolates investigated, and also included isolates that shared single nucleotide variations with another species, $C$. candelabrum. These findings suggest that $C$. pauciramosum most likely has a Central or South American center of origin.
\end{abstract}

Cylindrocladium pauciramosum C. L. Schoch \& Crous was recently described as a member of the Cylindrocladium candelabrum Viégas species complex (26). Cylindrocladium spp. are associated with Calonectria De Not. teleomorphs (24). Species are distinguished based on morphological features of the anamorph, such as conidium, vesicle, and phialide morphology, as well as cultural characteristics. Morphological features of the teleomorph tend to be more conserved, and species identification based on these characters alone is usually not possible (9).

C. candelabrum is a well-known root and leaf pathogen of numerous hosts. This species has regularly been confused with C. scoparium Morgan $(2,11,22)$. In order to distinguish these two species, C. scoparium was circumscribed as having ellipsoidal to pyriform vesicles, and isolates of C. candelabrum ellipsoidal to obpyriform vesicles (5). Mating studies have shown both these species to be distinct and heterothallic $(5,26)$.

Corresponding author: P. W. Crous

E-mail: pwc@maties.sun.ac.za

Accepted for publication 18 April 2001.

Publication no. D-2001-0625-02R

(C) 2001 The American Phytopathological Society
Previous studies delineated four genetically isolated mating populations within the boundaries of what was accepted to represent $C$. candelabrum (26). DNA sequencing confirmed these to be separate entities and, consequently, four species were described. One of these species, described as $C$. pauciramosum, is known from isolates collected in Australia, Brazil, Colombia, Mexico, and South Africa.

Published records indicate that $C$. pauciramosum has been associated with diseases of plants in South Africa for several years as either $C$. scoparium $(2,10,11,15)$ or $C$. candelabrum (5). Previous reports of a new disease attributed to $C$. scoparium from nurseries in Italy (22) were subsequently shown to be $C$. pauciramosum (23). In addition to this, another report confirmed the recent introduction of this fungus to California (14).

The phylogenetic relationship of $C$. scoparium to other heterothallic, small-spored Cylindrocladium spp. was recently investigated by means of DNA sequence comparisons $(25,27)$. Although previous work in this regard could distinguish closely related species based on small differences in the sequence of the 5.8S rDNA and flanking internal transcribed spacers (ITS1 and ITS2; 26), the low number of informative characters made phylogenetic determinations difficult. The use of DNA sequences obtained from additional areas, like the $\beta$-tubulin gene and the HMG box of the MAT-2 mating type gene, yielded higher variation and distinguished most species previously defined on other characters (25).

C. pauciramosum is self sterile. Female structures consist of protoperithecia, which can be spermatized by conidia or hyphae from an opposite mating type. A typical heterothallic ascomycete has been defined as a self-sterile hermaphrodite, capable of producing the female reproductive structures as well as male gametes (17). Generally, male functions can be performed by asexual spores, sexual spores, or hyphae. Observations in Gibberella fujikuroi have shown that the female function is lost regularly (16). These female sterile isolates can only act as males and were proposed to have a vegetative advantage during asexual reproduction, because no resources would be required for female reproductive structures. The opposite scenario was proposed for conditions favoring sex, resulting in a higher percentage of hermaphrodites (17). The ratios of the two mating types and of female steriles and hermaphrodites can be used to determine the importance of sexual replication and the effective population $\left(N_{\mathrm{e}}\right)$, giving an estimate of the size of a finite population as first proposed by Wright (33). These principles were reviewed by Caballero (4) and adapted for haploids (17). Recent studies $(3,19)$ made use of these assumptions in order to gain information on the effective population size and sexual dynamics of mating populations in the $G$. fujikuroi complex.

The goals of this study were, first, to determine the ratios of the two mating types in the newly recognized populations in Italy (22) and California (14), and, second, to compare this with a well-established South African population. A final aim was to obtain data relating to intraspecific variation of $C$. pauciramosum-based single nucleotide polymorphisms (SNPs) in a $\beta$ tubulin gene among isolates collected from a wide geographical area.

\section{MATERIALS AND METHODS}

Isolates. Isolates of $C$. pauciramosum were either obtained from symptomatic plant material or baited from soil samples (7). All isolates were identified using the morphological concepts, mating types, and keys as defined in earlier studies $(7,26)$. Isolates studied are listed in Table 1. 
South African isolates of C. pauciramosum were obtained from the culture collection at the Department of Plant Pathology at the University of Stellenbosch (STE-U; Table 1). These were collected throughout South Africa over a period from 1990 to 1995 and were obtained from diseased plant material as well as from soil. It was assumed that cultural preservation did not adversely affect mating ability because a recent subset from this collection produced successful crosses (26). An additional sample of 50 isolates was obtained from diseased crown and root tissues of individual cherry plants from a small nursery in Stellenbosch where this disease was recently recognized. Italian isolates were obtained from a number of nurseries in Sicily and Calabria (23). In all cases, isolates were randomly collected from hosts, one isolate per plant. In a similar manner, 50 isolates were collected from diseased crowns and roots of heath (Erica capensis Salter) from a single nursery in California.

Sexual compatibility. Two opposite mating tester strains (STE-U $416=$ MAT1, STE-971 = MAT-2) were selected for their high fertility during previous studies $(25,26)$. Single isolates were grown on petri dishes containing $2 \%$ malt extract agar (MEA; Biolab, Midrand, South Africa) for 2 to 4 weeks until sporulation.
Sterile water $(1 \mathrm{ml})$ was added to each petri dish and conidia were dislodged with the help of a sterile glass rod. The conidial suspension was removed with a micropipette. Cultures were spermatized by applying the conidial suspension to petri dishes containing carnation leaf agar (CLA) with 2- to 4-week-old growth. Colonized CLA plates of the selected cultures were respectively spermatized with the two tester strains. Furthermore, the tester strains also were spermatized by each of the selected isolates. Plates were subsequently packed in stacks, sealed in plastic bags, and incubated on the laboratory bench at $22^{\circ} \mathrm{C}$. Successful crosses were determined after 2 months of incubation and were regarded as those isolate combinations that produced perithecia with extruding, viable ascospores.

Statistical analysis. The effective population numbers were calculated according to Leslie and Klein (17). The effective population number based on mating type $\left(N_{\mathrm{e}(\mathrm{mt})}\right)$ was determined as $N_{\mathrm{e}(\mathrm{mt})}=\left(4 N_{\text {MAT }-1}\right.$ $\left.N_{\text {MAT- } 2}\right) /\left(N_{\text {MAT- } 1}+N_{\text {MAT- } 2}\right)$ with $N_{\text {MAT-1 }}$ the number of MAT-1 strains and $N_{\text {MAT-2 }}$ the number of MAT-2 mating-type strains. These are parameters to estimate genetic drift and inbreeding in populations. The inbreeding effective population $\left(N_{\mathrm{e}(\mathrm{f})}\right)$ is based on the probability of identity due to common ancestry and determined as $N_{\mathrm{e}(\mathrm{f})}=$ $\left(4 N^{2} N_{\mathrm{h}}\right) /\left(N+N_{\mathrm{h}}\right)^{2}$, with $N$ being the total number of individuals and $N_{\mathrm{h}}$ the total number of hermaphrodites.

Isolation of DNA, polymerase chain reaction amplification, and sequencing. Single conidial isolates selected for DNA comparisons (Table 2) were grown on MEA plates. Mycelial mats were removed from the plates by means of a sterile scalpel and ground to a powder with the help of liquid nitrogen and a mortar and pestle. Approximately $40 \mathrm{mg}$ of ground mycelia was added to 2-ml microtubes containing $600 \mu \mathrm{l}$ of extraction buffer. The extraction buffer consisted of $1 \%$ sodium dodecyl sulfate, $50 \mathrm{mM}$ Tris-HCl (pH 8.0), 150 $\mathrm{mM} \mathrm{NaCl}$, and $100 \mathrm{mM}$ EDTA. The subsequent protocol was followed as suggested for the Wizard Genomic DNA Purification kit (Promega Corp., Madison, WI). A 600bp fragment was amplified with the use of primers T1 (21) and Bt2b (13). Polymerase chain reaction (PCR) fragments were sequenced and amplified as described previously (26). Newly acquired sequences were deposited at GenBank (Table 2).

Phylogenetic analysis. The isolates selected for phylogenetic analysis are listed in Table 2. Alignments of sequences were done with the computer package Malign version 2.7 (32), assessed manually, and

Table 1. Isolates used for female fertility and mating type ratio determinations

\begin{tabular}{|c|c|c|c|c|}
\hline Isolate number & Location, province & Collector & Date & Host \\
\hline \multicolumn{5}{|l|}{ Italian isolates } \\
\hline DISTEF-G 3, 191, 192, 193, 194, 195, 196 & Lamezia location 1, Catanzaro & G. Polizzi & Jun. 1997 & Polygala myrtifolia \\
\hline DISTEF-G 173 & Lamezia location 2, Catanzaro & G. Polizzi & Nov. 1997 & Polygala myrtifolia \\
\hline DISTEF-G 75, 77, 79, 81, 127, 128 & Barcellona location 1, Messina & G. Polizzi & Oct. 1997 & Callistemon spp. \\
\hline DISTEF-G 149, 155, 158, 160, 162, 168 & Barcellona location 2, Messina & G. Polizzi & Oct. 1997 & Callistemon viminalis \\
\hline DISTEF-G 5, 6 & Milazzo, Messina & G. Polizzi & Sept. 1997 & Callistemon citrinus \\
\hline DISTEF-G 62, 67, 69, 74 & Milazzo, Messina & G. Polizzi & Oct. 1997 & Callistemon viminalis \\
\hline DISTEF-G 84, 87, 92, 96, 98, 104, 108, 115 & Milazzo, Messina & G. Polizzi & Oct. 1997 & Acacia retinodes \\
\hline DISTEF-G 10, 20, 31, 32 & Carruba, Catania & G. Polizzi & Sept. 1997 & Callistemon Mauve Mist \\
\hline DISTEF-G 9 & Carruba, Catania & G. Polizzi & Sept. 1997 & Metrosideros robustus \\
\hline DISTEF-G 40 & Carruba, Catania & G. Polizzi & Sept. 1997 & Eucalyptus viminalis \\
\hline DISTEF-G 46 & Carruba, Catania & G. Polizzi & Sept. 1997 & Callistemon citrinus \\
\hline DISTEF-G 50, 53, 60 & Carruba, Catania & G. Polizzi & Sept. 1997 & Myrtus communis \\
\hline DISTEF-G 124, 126 & Carruba, Catania & G. Polizzi & Oct. 1997 & Arbutus unedo \\
\hline DISTEF-G 199 & Praiola, Catania & G. Polizzi & Sept. 1994 & Myrtus communis \\
\hline DISTEF-G 186 & Praiola, Catania & G. Polizzi & Oct. 1994 & Eucalyptus rostrata \\
\hline DISTEF-G 1, 2 & Praiola, Catania & G. Polizzi & Jul. 1996 & Polygala myrtifolia \\
\hline DISTEF-G 21 & Praiola, Catania & G. Polizzi & Sept. 1997 & Metrosideros robustus \\
\hline DISTEF-G 183 & Grotte, Catania & G. Polizzi & Sept. 1994 & Eucalyptus rostrata \\
\hline DISTEF-G 175 & Grotte, Catania & G. Polizzi & Oct. 1994 & Metrosideros robustus \\
\hline DISTEF-G 23 & Grotte, Catania & G. Polizzi & Sept. 1997 & Myrtus communis \\
\hline \multicolumn{5}{|l|}{ South African isolates } \\
\hline STE-U 247, 249, 256, 257, 271, 273, 274, 344, 346 & Kwambonambi, Kwa-Zulu Natal & P. W. Crous & Feb. 1990 & Eucalyptus grandis \\
\hline STE-U 1239 & Kwambonambi, Kwa-Zulu Natal & P. W. Crous & Oct. 1995 & Eucalyptus grandis \\
\hline STE-U 391 & Pietermaritzburg, Kwa-Zulu Natal & P. W. Crous & Mar. 1990 & Eucalyptus nitens \\
\hline STE-U 575 & George, Western Cape & S. Lambrecht & Feb. 1993 & Azalea bushes \\
\hline STE-U 971, 972 & Knysna, Western Cape & P. W. Crous & Nov. 1994 & Soil \\
\hline STE-U 138, 143 & Kruisfontein, Mpumalanga & P. W. Crous & Feb. 1990 & Soil \\
\hline STE-U 356, 358 & Sabie, Mpumalanga & P. W. Crous & Feb. 1990 & Soil \\
\hline STE-U 286, 287, 288 & Klipkraal, Mpumalanga & P. W. Crous & Feb. 1990 & Soil \\
\hline STE-U 379, 380 & Witrivier, Mpumalanga & S. Lambrecht & May. 1990 & Azalea sp. \\
\hline STE-U $282-284$, & Tzaneen, Northern Province & P. W. Crous & Feb. 1990 & Soil \\
\hline STE-U 416, 417 & Tzaneen, Northern Province & P. W. Crous & Jun. 1990 & Pine cuttings \\
\hline STE-U 958, 959 & Piet Retief, Northern Province & P. W. Crous & Nov. 1994 & Eucalyptus grandis \\
\hline STE-U 2575-2630 & Stellenbosch, Western Cape & C. Linde & Apr. 1999 & Prunus sp. \\
\hline \multicolumn{5}{|l|}{ Californian isolates } \\
\hline STE-U 1982-2030 & California & S. Koike & 1998 & Erica capensis \\
\hline
\end{tabular}


deposited at GenBank and in TreeBase (SN612). Phylogenetic analysis of aligned DNA sequences was performed using a heuristic search with 500 random additions in PAUP* version $4.0 \mathrm{~b} 6$ (30). Gaps were treated as missing data. Confidence intervals were determined using 1,000 bootstrap replications in a simple heuristic search, with maxtrees set to 1,000 .

\section{RESULTS}

Effective population numbers based on ratios of mating types and female sterile hermaphrodites of the $C$. pauciramosum samples obtained from the selected areas are shown in Table 3. For the purpose of this study, mating capability of isolates was assumed not to be influenced by the host from which they were isolated, because species in the genus have been found not to be host specific and are essentially soilborne (26). More specific data about host specificity, epidemiology, mating, and other characteristics of these newly described species are still needed.

The values obtained in Table 3 reflect differences in the profiles for the various nurseries. Samples from various areas in South Africa, where the disease has been well established, tended to have a mating type ratio of approximately 1:1. All other samplings, representing areas where the disease has been recently introduced, yielded ratios that significantly favored one mating type. In the Stellenbosch nursery, the ratio favored the MAT-1 mating type, while the nurseries in Sicily had mostly MAT-2 isolates. Additionally, only the MAT-2 mating type was present in California. These figures differ appreciably from those obtained by other workers for species of the $G$. fujikuroi complex $(3,17,19)$, where the highest mating type ratio was near 1:2. Effective population numbers based on mating types $\left(\mathrm{N}_{\mathrm{e}(\mathrm{mt})}\right)$ of between 49 and $73 \%$ of the total count were inferred in the South African and Italian nurseries (Table 3). Higher effective population numbers were found based on the presence of hermaphrodites (Table 3), particularly for nurseries in California and Italy (98.4 to $99.8 \%$ ). A lower effective population based on this criterion was found for the South African isolates.

$\beta$-tubulin DNA sequence comparisons. Sequence comparisons based on DNA sequences of the $\beta$-tubulin gene have previously been used to investigate phylogeny in C. scoparium, C. pauciramosum, and related species (26). In the present study, an investigation on the variation in C. pauciramosum was undertaken. C. candelabrum, C. multiseptatum, and Fusarium subglutinans were used as outgroups. As far as possible, six isolates of opposing mating type from disparate regions within a country were used for comparison. The groups indicated in a neighbor-joining dendrogram agreed with the clades seen in the 10 most parsimonious trees (MPTs) found under a heuristic search. A strict consensus tree obtained from these is presented in Figure 1. The only difference between the individual parsimonious trees was in the placement of isolate STE-U 1671. When this isolate was removed from the data set, a heuristic search resulted in only two MPTs. In one of these trees, the South American isolates of $C$. pauciramosum (clade 2) grouped with isolates of $C$. candelabrum (clade 1) and STE-U 1670, while in the other tree these clades remained separate. No change was observed in the groups delineated in Figure 1 when different outgroup rootings were employed.

From a comparison between $C$. candelabrum and C. pauciramosum, 27 SNPs were found out of a data set of 521 unordered characters. This is comparable to and consistent with the low amount of variation previously observed between species of Cylindrocladium in the ITS1 and 2 spacers opposite to the 5.8S ribosomal RNA gene $(6,26)$. The low number of informative characters (in some cases, a single character) was reflected by the low bootstrap

Table 2. Isolates of Cylindrocladium pauciramosum and other species selected for sequence comparisons of a portion of the $\beta$-tubulin gene

\begin{tabular}{|c|c|c|c|}
\hline Species, accession no. & GenBank no. & Host & Origin \\
\hline \multicolumn{4}{|l|}{ F. subglutinans } \\
\hline NRRL 22016 & U34417 & $\ldots$ & $\ldots$ \\
\hline \multicolumn{4}{|l|}{ C. pauciramosum } \\
\hline STE-U 143 & AF320200 & Eucalyptus grandis & Mpumalanga, South Africa \\
\hline STE-U 344 & AF320201 & Eucalyptus grandis & Kwa-Zulu Natal, South Africa \\
\hline STE-U 416 & AF210869 & Eucalyptus grandis & Northern Province, South Africa \\
\hline STE-U 913 & AF320202 & Soil & Santa Catarina, Brazil \\
\hline STE-U 925 & AF210870 & Soil & Santa Catarina, Brazil \\
\hline STE-U 951 & AF320203 & Soil & Veracruz, Mexico \\
\hline STE-U 971 & AF320204 & Eucalyptus grandis & Western Cape, South Africa \\
\hline STE-U 972 & AF210871 & Eucalyptus grandis & Western Cape, South Africa \\
\hline STE-U 1160 & AF320205 & Soil & Córdoba, Colombia \\
\hline STE-U 1670 & AF320206 & Eucalyptus sp. & Bahia, Brazil \\
\hline STE-U 1671 & AF320207 & Eucalyptus sp. & Bahia, Brazil \\
\hline STE-U 1691 & AF320208 & Fragaria sp. & Queensland, Australia \\
\hline STE-U 1692 & AF320209 & Fragaria $\mathrm{sp}$. & Queensland, Australia \\
\hline STE-U 1990 & AF320210 & Erica capensis & California, USA \\
\hline STE-U 2030 & AF320211 & Erica capensis & California, USA \\
\hline DISTEF-G 2 & AF320212 & Polygala myrtifolia & Catania, Sicily, Italy \\
\hline DISTEF-G 6 & AF320213 & Callistemon citrinus & Messina, Sicily, Italy \\
\hline DISTEF-G 60 & AF320214 & Myrtus communis & Catania, Sicily, Italy \\
\hline DISTEF-G 62 & AF320215 & Callistemon citrinus & Messina, Sicily, Italy \\
\hline DISTEF-G 84 & AF320216 & Acacia retinodes & Messina, Sicily, Italy \\
\hline DISTEF-G 126 & AF320217 & Arbutus unedo & Catania, Sicily, Italy \\
\hline DISTEF-G 127 & AF320218 & Callistemon citrinus & Messina, Sicily, Italy \\
\hline DISTEF-G 128 & AF320219 & Callistemon citrinus & Messina, Sicily, Italy \\
\hline DISTEF-G 192 & AF320220 & Polygala myrtifolia & Catanzaro, Calabria, Italy \\
\hline DISTEF-G 196 & AF320221 & Polygala myrtifolia & Catanzaro, Calabria, Italy \\
\hline \multicolumn{4}{|l|}{ C. candelabrum } \\
\hline STE-U 1674 & AF210857 & Eucalyptus sp. & Brazil \\
\hline STE-U 1677 & AF210858 & Eucalyptus sp. & Amazonas, Brazil \\
\hline STE-U 1951 & AF210859 & Soil & Brazil \\
\hline UFV 89 & AF320199 & Soil & Brazil \\
\hline \multicolumn{4}{|l|}{ C. mexicanum } \\
\hline STE-U 927 & AF210863 & Soil & Yucatan, Mexico \\
\hline STE-U 941 & AF210864 & Soil & Campeché, Mexico \\
\hline \multicolumn{4}{|l|}{ C. multiseptatum } \\
\hline STE-U 1589 & AF210865 & Eucalvptus sp. & Indonesia \\
\hline STE-U 1602 & AF210866 & Eucalyptus sp. & Indonesia \\
\hline
\end{tabular}

Table 3. Comparison of the distribution of mating type and hermaphrodites among isolates of Cylindrocladium pauciramosum from three geographic areas

\begin{tabular}{lcccc}
\hline & & \multicolumn{3}{c}{$\mathbf{N}_{\mathbf{e}}$ (effective population) } \\
\cline { 2 - 5 } Geographic origin & Ratio $^{\mathbf{b}}$ & $\mathbf{N}_{\mathbf{f s}}: \mathbf{N}_{\mathbf{h}} \mathbf{c}$ & $\mathbf{N}_{\mathbf{e}(\mathbf{m t})}{ }^{\mathbf{d}}$ & $\mathbf{N}_{\mathbf{e}(\mathbf{f})} \mathbf{e}$ \\
\hline South Africa: Stellenbosch nursery & $48: 8$ & $31: 25$ & 49.0 & 85.3 \\
Elsewhere in South Africa & $21: 23$ & $29: 15$ & 99.7 & 75.8 \\
United States: California nursery & $0: 50$ & $4: 46$ & 0 & 99.8 \\
Italy: various nurseries & $13: 41$ & $12: 42$ & 73.1 & 98.4 \\
\hline
\end{tabular}

a Effective population number based on the numbers of males $\left(N_{\mathrm{fs}}\right)$ and hermaphrodites $\left(N_{\mathrm{h}}\right)$ as percentage of the actual count.

${ }^{\mathrm{b}}$ Mating type ratio as MAT-1:MAT-2; data from Schoch et al. (26).

${ }^{\mathrm{c}}$ Ratio of female sterile: hermaphrodites in the population.

${ }^{\mathrm{d}}$ Effective population number based on mating type ratios (17).

${ }^{\mathrm{e}}$ Inbreeding effective number based on numbers of female steriles and hermaphrodites (17). 
values seen in Figure 1. In order to show the variation at sequence level, the SNPs are presented as numbered boxes or circles in Figure 1. Variable characters were almost exclusively situated in the noncoding regions of the $\beta$-tubulin gene. Only two characters (base pairs 273 and 348) were inside the coding regions.

The $C$. candelabrum isolates obtained from Brazil (group 1; Fig. 1) had identical sequences. Although $C$. candelabrum is closely related to $C$. pauciramosum, these two species have been shown to differ biologically and genetically (26). The $C$. candelabrum isolates (clade 1) shared a

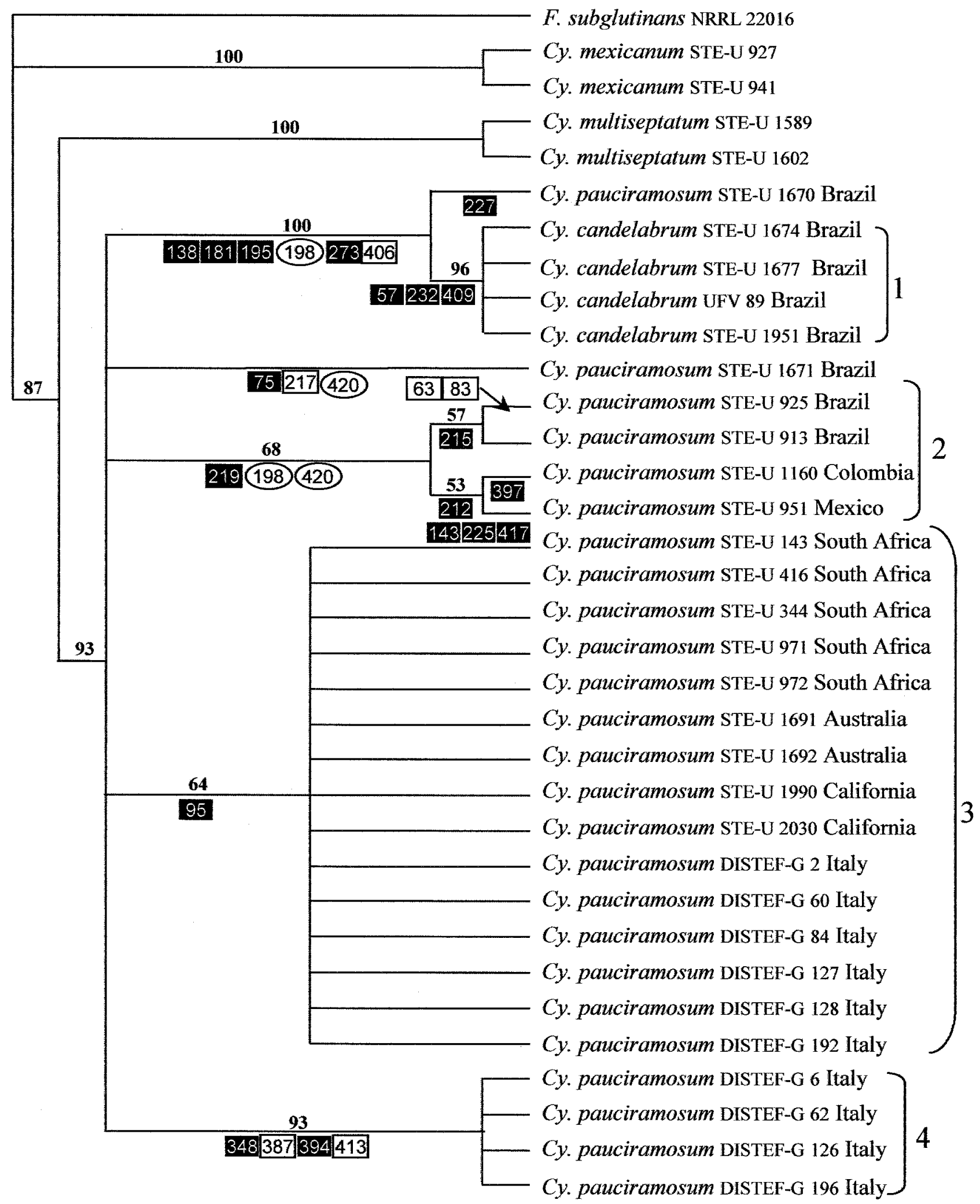

Fig. 1. A strict consensus tree of 10 most parsimonious trees obtained by a heuristic comparison of DNA sequences from the $5^{\prime}$ end of the $\beta$-tubulin gene. Clade stability was assessed by 1,000 bootstrap samplings (percentages shown above branches). Individual single nucleotide polymorphisms are shown beneath branches. Numbers denote base pair positions. Transitions are indicated with solid (black) shapes and tranversions with open (white) shapes. Unique derived characters for a specific group or isolate are indicated as squares and shared characters as circles. 
total of nine SNPs, of which three (base pairs 57,232 , and 409) were unique for all isolates in this group. The remaining six SNPs were shared by group 2 with an isolate of $C$. pauciramosum, STE-U 1670. This isolate clustered with $C$. candelabrum in Figure 1 but still grouped separate and had one unique SNP (base pair 227). One SNP separated clades 1, 2, and STE-U 1670 (base pair 198).

Variation was found for other individual C. pauciramosum isolates from South America and Mexico. Three SNPs supported clade 2. In addition to base pair 198 mentioned above, base pair 420 was shared with STE-U 1671. Although most of the variation occurred among Latin American isolates, no variable characters were shared with any of the isolates from the other geographic regions (South Africa, Australia, and Italy).

Isolates in clade 3 selected from the South African, Italian, and California populations had identical sequences but clustered together with no bootstrap support. This group differs by one unique character at base pair 95. A different group of Italian isolates had four unique base pair substitutions in close proximity to each other (clade 4) and had high (93\%) bootstrap support (Fig. 1).

\section{DISCUSSION}

The results presented here showed fundamental differences in the profiles of the populations sampled. The nursery populations may have been founder populations and it is likely that some could have gone through recent population bottlenecks. This is reflected in the varying ratios of mating types found in the different nurseries and different geographic areas. The only population that approached a 1:1 mating type ratio was the South African sample, where the disease has been well established. These isolates were collected over a wide area over several years. All the Italian samples had the same mating type bias, suggesting a single source; namely, the nursery in Carruba, which supplies the other local nurseries. The low effective population, based on the number of hermaphrodites in this nursery, could be due to a persistent occurrence of the pathogen in this nursery under selective conditions for asexuality.

The high ratios of hermaphrodites in the samples agree with the recent introductions reported in the literature $(22,23)$. However, the percentage of hermaphrodites found in the various nurseries is consistent with a mother population that is sexually reproductive $(3,17)$. One would expect the percentage of hermaphrodites to drop if a single mating type persists in a nursery. However, the application of good nursery practices entails the immediate removal of diseased material and has the potential to create new bottlenecks due to small starter populations on the remaining plants. The influx of new diseased material containing the opposite mating type could further influence population dynamics.

Plant pathogens are commonly brought into the nursery by means of infected plant material or soil. The most important survival strategy of Cylindrocladium spp. is microsclerotia, which can survive for periods of up to 15 years and longer in soil (29,31). Under suitable climatic conditions, germination and subsequent infection of roots and leaves can occur $(1,28)$. The conidia form on infected plant material and are splash dispersed between closely spaced plants (20). In the case of sexual reproduction, the ascospores can also be an additional source of inoculum and are generally wind dispersed (8). The profiles of the mating type distributions seen in this study are consistent with the effects seen for a small starter population, probably by asexual propagules in plants and soil. The fact that only one mating type was found in California, as well as the strong bias towards one mating type in the Italian sample, emphasizes that sexual reproduction may play a small role in these populations.

Genetic variation based on DNA sequence data also was detected between different isolates of $C$. pauciramosum. Although the gene tree based on partial sequences of the $\beta$-tubulin gene may not accurately reflect species phylogeny $(12,18)$, recent analyses of different loci have produced concordant phylogenies for C. pauciramosum and closely related species (25). Thus, if the assumption that the variation in the $\beta$-tubulin gene DNA sequences reflects recent evolutionary history is correct, we can see a correlation of clades with the geographic origin of isolates.

Although isolates have previously been shown to belong to a single biological species $(25,26)$, shared $\beta$-tubulin characters were found among isolates of $C$. pauciramosum and C. candelabrum, underlining their close phylogenetic relationship.

The high variation among South and Central American isolates of $C$. pauciramosum is consistent with an endemic population, but the small sample size precludes a more thorough assessment. Isolates from California, South Africa, Italy, and Australia differed slightly from the Latin American isolates in $\beta$-tubulin sequences. The identical sequence data obtained from the South African isolates suggests that this population was introduced. DNA sequences obtained from isolates collected from Australia, South Africa, Italy, and California were also identical and could indicate a common source of inoculum. There is anecdotal evidence of importation of South African nursery material into Italian nurseries. The occurrence of another DNA sequence from Italy complicates this issue, however. This allows for the possibility of more than one introduction of this species into Italy.
Because of the small sample sizes and use of only one locus, it must be emphasized that this is a first approximation of the variation present in geographic populations of $C$. pauciramosum. A more detailed study of genetic and mating markers will allow more comprehensive conclusions to be drawn. In spite of this, these results emphasize the importance of correct identification of the members of morphologically closely related species in the $C$. candelabrum complex in order to aid phytosanitation and quarantine practices.

\section{LITERATURE CITED}

1. Anderson, N., French, D. W., and Taylor, D. P. 1962. Cylindrocladium root rot of conifers in Minnesota. For. Sci. 8:378-384.

2. Botha, W. J., and Crous, P. W. 1992. A wilt disease of Rhododendron caused by Pythium prolatum and Cylindrocladium scoparium. Phytophylactica 24:75-78.

3. Britz, H., Wingfield, M. J., Coutinho, T. A., Marasas, W. F. O., and Leslie, J. F. 1998. Female fertility and mating type distribution in a South African population of Fusarium subglutinans f. sp. pini. Appl. Environ. Microbiol. 64:2094-2095.

4. Caballero, A. 1994. Developments in the prediction of effective population size. Heredity 73:657-679.

5. Crous, P. W., Alfenas, A. C., and Wingfield, M. J. 1993. Calonectria scoparia and $\mathrm{Ca}$ lonectria morganii sp. nov. and variation among isolates of their Cylindrocladium anamorphs. Mycol. Res. 97:701-708.

6. Crous, P. W., Kang, J. C., Schoch, C. L., and Mchau, G. R. A. 1999. Phylogenetic relationships of Cylindrocladium pseudogracile and Cylindrocladium rumohrae with morphologically similar taxa, based on morphology and DNA sequences of internal transcribed spacers and $\beta$-tubulin. Can. J. Bot. 77:1813-1820.

7. Crous, P. W., Mchau, G. R. A., Van Zyl, W. H., and Wingfield, M. J. 1997. New species of Calonectria and Cylindrocladium isolated from soil in the tropics. Mycologia 89:653660 .

8. Crous, P. W., Phillips, A. J. L., and Wingfield, M. J. 1991. The genera Cylindrocladium and Cylindrocladiella in South Africa, with special reference to forest nurseries. S. Afr. For J. 157:69-85.

9. Crous, P. W., and Wingfield, M. J. 1994. A monograph of Cylindrocladium, including anamorphs of Calonectria. Mycotaxon 51:341-345.

10. Darvas, J. M., Scott, D. B., and Kotzé, J. M. 1978. Fungi associated with damping-off in coniferous seedlings in South African nurseries. S. Afr. For. J. 104:15-19.

11. Doidge, E. M. 1950. The South African fungi and lichens to the end of 1945. Bothalia 5:11094.

12. Doyle, J. J. 1992. Gene trees and species trees: molecular systematics as one-character taxonomy. Syst. Bot. 17:144-163.

13. Glass, N. L., and Donaldson, G. 1995. Development of primer sets designed for use with PCR to amplify conserved genes from filamentous ascomycetes. Appl. Environ. Microbiol. 61:1323-1330.

14. Koike, S. T., Henderson, D. M., Crous, P. W., and Schoch, C. L. 1999. A new root and crown rot disease of heath in California caused by Cylindrocladium pauciramosum. Plant Dis. 83:589.

15. Lamprecht, S. C. 1986. A new disease of Medicago truncatula caused by Cylindrocladium scoparium. Phytophylactica 18:111-114.

16. Leslie, J. F. 1995. Gibberella fujikuroi: avail- 
able populations and variable traits. Can. J. Bot. 73:S282-S291.

17. Leslie, J. F., and Klein, K. K. 1996. Female fertility and mating type effects on effective population size and evolution in filamentous fungi. Genetics 144:557-567.

18. Maddison, W. 1997. Gene trees in species trees. Syst. Biol. 46:523-536.

19. Mansuetus, A. S. B., Odvody, G. N., Frederiksen, R. A., and Leslie, J. F. 1997. Biological species in the Gibberella fujikuroi species complex (Fusarium section Liseola) recovered from sorghum in Tanzania. Mycol. Res. 101:815-820.

20. Mohanan, C., and Sharma, J. K. 1986. Epidemiology of Cylindrocladium diseases of Eucalyptus. Pages 388-394 in: Eucalypts in India: Past, Present, and Future. J. K. Sharma, C. T. S. Nair, S. Kedharnath, and S. Kondas, eds. Kerala Forest Research Institute, Peechi, India.

21. O'Donnell, K., and Cigelnik, E. 1997. Two divergent intragenomic rDNA ITS2 types within a monophyletic lineageof the fungus Fusarium are nonorthologous. Mol. Phylogenet. Evol. 7:103-116.
22. Polizzi, G., and Azzaro, A. 1996. A new leaf spot disease of myrtle by Cylindrocladium scoparium and its control in the nursery. Petria 6:117-123.

23. Polizzi, G., and Crous, P. W. 1999. Root and collar rot of milkwort caused by Cylindrocladium pauciramosum, a new record for Europe. Eur. J. Plant Pathol. 105:413-415.

24. Rossman, A. Y. 1979. A preliminary account of the taxa described in Calonectria. Mycotaxon 8:485-558.

25. Schoch, C. L., Crous, P. W., Cronwright, G., Witthuhn, R. C., El-Gholl, N. E., and Wingfield, B. D. 2000. Recombination in Cylindrocladium scoparium and phylogeny to other heterothallic small spored Cylindrocladium species. Mycologia 92:665-673.

26. Schoch, C. L., Crous, P. W., Wingfield, B. D., and Wingfield, M. J. 1999. The Cylindrocladium candelabrum species complex includes four distinct mating populations. Mycologia 91:286-298.

27. Schoch, C. L., Crous, P. W., Wingfield, M. J., and Wingfield, B. D. 2000. Phylogeny of $\mathrm{Ca}$ lonectria and selected hypocrealean genera with cylindrical macroconidia. In: Molecules,
Morphology and Classification: Towards Monophyletic Genera in the Ascomycetes. K. A Seifert, W. Gams, P. W. Crous, and G. J. Samuels, eds. CBS, Utrecht, The Netherlands. Stud. Mycol. 45:45-62.

28. Sharma, J. K., Mohanan, C., and Florence, E. J. M. 1990. Diseases of forest trees in Kerala. 6. Leaf diseases of eucalypts in plantations. Evergreen Trichur. 25:12-15.

29. Sobers, E. K., and Litrell, R. H. 1974. Pathogenicity of three species of Cylindrocladium to select hosts. Phytopathology 58:10171019.

30. Swofford, D. L. 2001. PAUP* Phylogenetic analysis using parsimony (*and other methods). Version 4b6. Computer program. Sinauer Associates, Sunderland, MA

31. Thies, W. G., and Patton, R. F. 1970. The biology of Cylindrocladium scoparium in Wisconsin forest tree nurseries. Phytopathology 60:1662-1668.

32. Wheeler, W., and Gladstein, D. 1991. Malign. Version 2.7. Computer program. American Museum of Natural History, New York.

33. Wright, S. 1931. Evolution in Mendelian populations. Genetics 16:97-15. 